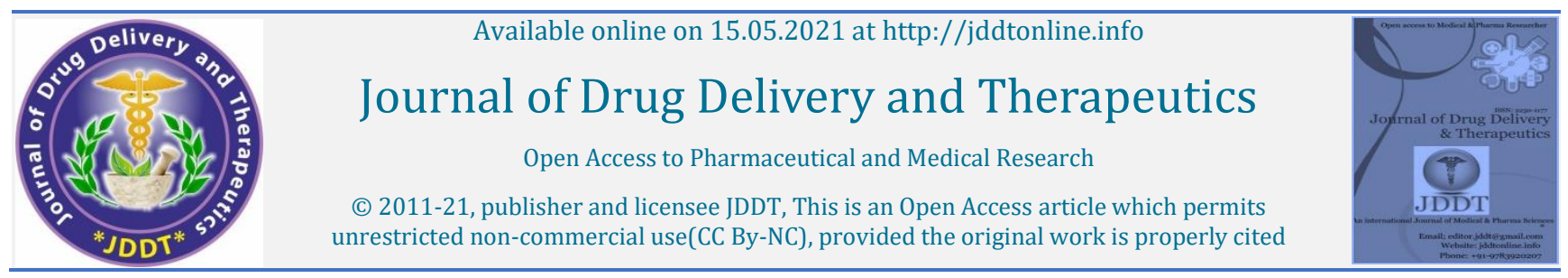

\title{
Antibiotic Susceptibility Pattern of Bacterial Pathogens Isolated from Ethiopian Paper Currency Notes in Wolaita Sodo, Southern Ethiopia
}

\author{
Krishna Moorthy Sivalingam ${ }^{1 *}$ and Dawit Leja Dola ${ }^{2}$ \\ ${ }^{1}$ Department of Biology, College of Natural and Computational Sciences, Wolaita Sodo University, Wolaita Sodo, Ethiopia \\ ${ }^{2}$ Department of Biotechnology, College of Natural and Computational Sciences, Wolaita Sodo University, Wolaita Sodo, Ethiopia
}

\begin{tabular}{ll}
\hline Article Info & \\
\hline & Article History: \\
& Received 08 March 2021 \\
& Pubepted 23 April 2021 \\
&
\end{tabular}

\section{Cite this article as:}

Sivalingam KM, Dola DL, Antibiotic Susceptibility Pattern of Bacterial Pathogens Isolated from Ethiopian Paper Currency Notes in Wolaita Sodo, Southern Ethiopia, Journal of Drug Delivery and Therapeutics. 2021; 11(3):23-30

DOI:http://dx.doi.org/10.22270/jddt.v11i3.4704

\section{*Address for Correspondence:}

Dr. S. Krishna Moorthy, Associate Professor, Department of Biology, B-062, College of Natural and Computational Sciences, Wolaita Sodo University, Post Box No. 138, Wolaita Sodo, Ethiopia

\begin{abstract}
The present study was conducted to isolate pathogenic bacteria and their antimicrobial resistance pattern from Ethiopian paper currency notes in Wolaita Sodo town. A total of 240 Ethiopian paper currency notes samples in different denominations were collected from four different sources such as market, taxi drivers, fruit sellers and hotels. All the samples were processed to isolate bacterial pathogens using standard techniques and identified by different biochemical tests. Further all identified isolates were used to know the sensitivity/resistant patterns by Bauer-Kirby method based on the zone formation. Out of 240 paper currency notes samples, 120 were showed positive with four different genus such as Staphylococcus aureus, Escherichia coli, Shigella sp. and Salmonella sp. Among these four different genera, S. aureus were highly prevalent $(20.8 \%)$ followed by E. coli (14.58\%), Shigella sp. (10.81\%), and Salmonella sp. (3.74\%). From the selected four different sources of currency notes such as market, taxi drivers, fruit sellers and hotel, currency notes collected from market area showed the highest rate of contamination followed by taxi drivers, fruit sellers and hotel. S.s aureus, E. coli, Salmonella spp. and Shigella sp. showed resistivity varied from $70-100 \%$ against all the antibiotics. Tobramycin showed $20 \%$ effective against S. aureus, $11.5 \%$ effective against Shigella spp. and $33 \%$ effective against Salmonella spp. while E. coli showed $14 \%$ sensitivity against Metronidazole antibiotics. Therefore, the present study concludes that the Ethiopian Paper currency notes contaminated with bacterial pathogens and play significant role in the transmission of human pathogenic microorganisms.
\end{abstract}

Keywords: Prevalence, Pathogenic bacteria, Paper Currency and Antimicrobial susceptibility

\section{INTRODUCTION}

Paper Currency notes are widely used for exchange of commodity, goods, and services globally. While so, currency notes could be contaminated with numerous pathogenic microbial floras including bacteria, fungi and virus; and acts as a carrier for the transmission of pathogenic microorganisms among humans via unhygienic conditions and habits.1,2 The paper currency notes can be contaminated by several activities like sneezing and coughing on hands, nose picking followed by exchanging currency notes, applying saliva on fingers to assist counting of currency notes, storage of currency note on contaminated surfaces and improper hand wash after using toilets. ${ }^{3}$ The Ethiopian paper currency called Birr (ETB) is the second most used currency in Africa after Nigerian "Naira" for goods and services in African continent. 4,5

Paper currency has rough surface that provides a good niche for microorganisms and other particulates to settle and accumulate over long term and thereby constitute a potential source of infection. The levels and diversity of microbial contamination of currency notes depend on several factors including the period of their circulation, handling and its texture. The capacity of currency notes to absorb moisture also facilitates the growth and viability of microorganisms. 6,7 Micro floral load of Bacilli, Coccus, Fungal species $^{5}$ from Axum-Ethiopia, Streptococcus species, Micrococcus species, Staphylococcus, Enterobacteriaceae, ${ }^{4}$ from Jimma-Ethiopia were reported from Ethiopian Birr. Microbial contaminated currency rate handled by food sellers $(62.1 \%)$ and butchers (78.0 \%) was also reported from Nepal. ${ }^{8}$

The pathogenic or potentially pathogenic bacteria found on these currency notes may cause a wide variety of diseases from food poisoning through contaminated Staphylococcus which may produce enterotoxin, wound and skin infections, respiratory and gastrointestinal problems to life threatening diseases such as meningitis and septicaemia. Microbial contamination of paper money is not only confined to developing nations. Several studies from United States reported contamination of coins and paper bills and the identification revealed the presence of pathogenic microbes. ${ }^{9}$ Infectious diseases caused by pathogenic microflorae on paper currency notes are principally bacterial and many of them controlled by treatment with antibiotics. ${ }^{10}$ Resistance to antibiotic treatment by some of these bacteria had claimed millions of lives despite massive investments and efforts to decline the difficulties. ${ }^{11}$ 
Therefore, the aim of this study was to isolate and identify the pathogenic bacteria and their antibiotic resistant pattern of Ethiopian paper currency notes collected from Wolaita Sodo, Southern Ethiopia.

\section{MATERIALS AND METHODS}

\section{Sample source}

The sample source was currency notes (Ethiopian birr) which were currently functional and collected from four occupational of marketing system (i.e., Local market, Hotel, Taxi drivers, and Fruit sellers) in Wolaita Sodo, Southern Ethiopia.

\section{Sample size determination}

Sample size determination for contamination of paper currency notes was estimated at $19.5 \%$ (prevalence of Pathogenic bacteria Staphylococcus aureus), therefore by applying the formula according to Haile and Mogessie, ${ }^{12}$ the sample size (n) was obtained as below;

$$
n=\frac{z_{\alpha}^{2} p *(1-p)}{d^{2}}
$$

In the formula, $\mathrm{n}=$ sample size $\mathrm{Z}$ (Confidence interval) $=1.96$ $\mathrm{p}$ (estimated prevalence) $=19.5 \%$ (.195) $\mathrm{d}$ (allowable error) $=5 \%(0.05)$

$$
n=\frac{1.96^{2} 0.195 *(1-0.195)}{0.05^{2}}
$$

$\mathrm{n}=240$ (1=contingency)

\section{Collection of samples}

Totally 240 currency samples were collected from the study area. Among these 240 samples, each 60 samples were collected from different occupational groups such as market, hotels, taxi drivers and fruit sellers. At presently, four different denominations such as 5, 10, 50 and 100-Birr currency notes are circulated for their transactions. Therefore, 15 samples of each currency from each occupational group were collected for the present study. To collect the paper currency, the individuals were requested to drop the currency notes in to a sterile polyethene bag and immediately transported to Wolaita Sodo University Post Graduate Microbiology laboratory for subsequent analysis.

\section{Determination of standard plate count}

The Sterile cotton swab was dipped in the sterile peptone water and was rubbed on both the surfaces of currency notes. Agitated for 2 minutes to wash all contents of contamination from cotton swab and the resulting solution was added with $10 \mathrm{ml}$ of sterile peptone water. $1 \mathrm{ml}$ of the resulting solution was serially diluted up to $10^{-6}$ magnitude. $0.1 \mathrm{ml}$ of sample homogenate from serial dilutions was introduced on to the sterile plate count agar (Oxoid, UK) plates. The plates were labeled using a marker and then incubated at $37^{\circ} \mathrm{C}$ for 24 hours to 48 hours to allow growth. The number of colonies were counted after 24 hours using a colony counter which were converted to colony forming units using the formula below; ${ }^{13}$

Colony Forming Units (CFU) = Number of Colonies $\mathrm{x}$ Dilution Factor/Volume of culture plate

\section{Enrichment of currency notes samples}

All positive samples were further inoculated in $100 \mathrm{ml}$ of nutrient broth ( $1 \mathrm{ml}$ positive SPC sample) and enriched for growth of bacteria at $37^{\circ} \mathrm{C}$ for 16 to 24 hours. Further these samples were used for selective isolation.

\section{Selective media isolation}

After completion of enrichment process, from the enrichment broth aseptically the inoculums were transferred to different selective media, such as Endo agar for Escherichia coli, Salmonella and Shigella agar for Salmonella spp., and Shigella spp., Mannitol Salt Agar for Staphylococcus aureus. ${ }^{14}$

\section{Identification based on colony morphology and biochemical tests}

Bacterial strains were morphologically identified based on morphology of colony and cell structure and arrangements using Gram's staining reaction. Identification was further extended with biochemical tests which include; motility, catalase, indole production and oxidase test.

\section{Maintenance and preservation of culture strains}

The organisms grown in appropriate media for 18 hours was preserved in a nutrient agar slant at $2-8^{\circ} \mathrm{C}$ in refrigerator and the culture was used within two weeks for routine laboratory works. For long term preservation, strains were stored in brain heart infusion broth (BHIB) (HI MediaLQ210D) with $20 \%$ glycerol and store froze without significant loss of viability at $-20 \mathrm{C}$ until further study. ${ }^{15}$

\section{Antimicrobial susceptibility testing}

All the clinical isolates were tested for their sensitivity and resistant pattern by disc diffusion method. ${ }^{16}$ The culture plates were prepared by pouring $20 \mathrm{ml}$ of Mueller Hinton agar (MHA) (HiMedia-M173). The depth of the medium was approximately $4 \mathrm{~mm}$. Three to four similar colonies of pure cultures will be inoculated with tryptone soy broth (HiMedia-M323). Further, it was inoculated at $37^{\circ} \mathrm{C}$ for $2-8$ hours and inoculums size will be adjusted to yield uniform suspension containing 10-10 cells/ml (Mc Farland's standard). The agar surface of the plates was swabbed in three directions, turning the plates at 60 between each swabbing. Confluent growth is desirable for accurate results. A total of twelve antibiotics were used for disc diffusion test. The antibiotic disc was placed over the surface of swabbed medium with equal distance to avoid the overlapping of the zone of inhibition. Then the discs were pressed gently on the surface of the medium and allowed to stand in refrigerator for 30 minutes (pre-diffusion time). The plates were incubated at $37^{\circ} \mathrm{C}$ for $16-18$ hours during which the results were appeared by the presence of zone of inhibition surrounding the discs. Each experiment will be done in triplicate. As per the CLSI guideline, the result was interpreted. Bacterial isolates were tested for the following commonly prescribed drugs: erythromycin $(15 \mu \mathrm{g})$, penicillin $(10 \mu \mathrm{g})$, metronidazole $(5 \mu \mathrm{g})$, amoxicillin-clavulanic acid $(30 \mu \mathrm{g})$, ceftriaxone $(30 \mu \mathrm{g})$, kanamycin $(5 \mu \mathrm{g})$, tetracycline $(30 \mu \mathrm{g})$, cotrimoxazole $(25 \mu \mathrm{g})$, azithromycin $(15 \mu \mathrm{g})$, tetracycline $(30 \mu \mathrm{g})$, tobramycin $(30 \mu \mathrm{g})$, clarithromycin $(15 \mu \mathrm{g})$ and cefoxitin $(30 \mu \mathrm{g})$.

\section{References strains}

Escherichia coli (ATCC-25922) and Enterococcus spp. (ATCC29212) was used as a quality control throughout the study for culture and antimicrobial susceptibility testing. All the strains obtained from Ethiopian Public Health Institute, Addis Ababa, Ethiopia.

\section{Data Analysis}

Response to antibiotics was recorded as either sensitive (S), Intermediate (I), or Resistant (R). All the data was entered into the computer subsequently analyses using MS Excel 2010 package for windows. 


\section{RESULTS}

\section{Isolation and identification of bacterial pathogens}

The present study was focused on the isolation of pathogenic bacteria and their antimicrobial resistance pattern from Ethiopian paper currency note, Southern Ethiopia, during the study period of December 2019 to April 2020. A total of 240 paper currency samples were collected aseptically from different sources like Taxi drivers, market places, fruit sellers and hotels. All the collected paper currency denominations (240) were used to determine total aerobic mesophilic bacterial count (TAMBC) by spread plate technique. The results in the Table 1 showed that 120 paper currency samples showed positive from the total samples size of 240 . Among these 120 positive currency samples, 53 positives were found to be in the 5birr currency denomination, 32 positive samples were obtained from the 10birr currency denominations, 22 and 13 positive samples were found to be with 50birr and 100birr paper currency denominations respectively. The result in the table- 1 also revealed that the mean value of the total aerobic mesophilic bacterial count was higher in the 5-birr $(6.3 \pm 0.61)$ and 10 birr (4.8 \pm 0.27$)$ currency denominations followed by 50birr $(2.7 \pm 0.18)$ and 100birr $(1.8 \pm 0.32)$ denominations. Further all the 120 positive isolates were allowed to identify based on the morphological and biochemical characteristics.

Table 1: Total Aerobic Mesophilic Bacterial Counts (CFU/cm2) of Ethiopian paper currency notes.

\begin{tabular}{|l|l|l|l|l|}
\hline $\begin{array}{l}\text { S. } \\
\text { No. }\end{array}$ & $\begin{array}{l}\text { Paper Currency } \\
\text { Denominations }\end{array}$ & Sample size & $\begin{array}{l}\text { Positive } \\
\text { sample }\end{array}$ & $\begin{array}{l}\text { Total Aerobic Mesophilic Bacteria Mean } \pm \text { SD } \\
\text { (CFU/cm2) }\end{array}$ \\
\hline 1 & 5 birr & 60 & 53 & $6.3 \pm 0.61$ \\
\hline 2 & 10 birr & 60 & 32 & $4.8 \pm 0.27$ \\
\hline 3 & 50 birr & 60 & 22 & $2.7 \pm 0.18$ \\
\hline 4 & 100 birr & 60 & 13 & $1.8 \pm 0.32$ \\
\hline Total samples & $\mathbf{2 4 0}$ & $\mathbf{1 2 0}$ & $\mathbf{3 . 9 \pm 0 . 3 4}$ \\
\hline
\end{tabular}

Morphological and biochemical characteristics of four different genera (Staphylococcus aureus, Escherichia coli, Shigella species and Solmonella species) are indicated in the Table 2 \& Table 3 . Table 2 showed colony characters of isolated bacterial species from various denominations of
Ethiopian paper currency notes. All the isolates were inoculated in MacConkey agar and Selective media of concern bacterial isolates and confirmed accordingly. Table 3 showed the result of preliminary characters of bacterial pathogens isolated from paper currency notes.

Table 2: Preliminary identification of bacterial isolates based on colony morphology

\begin{tabular}{|l|l|l|}
\hline \multirow{2}{*}{ Bacterial Species } & \multicolumn{2}{|c|}{ Colony Morphology } \\
\cline { 2 - 3 } & MacConkey Agar & Selective Agar \\
\hline Staphylococcus aureus & Lactose fermenting yellow coloured colonies & $\begin{array}{l}\text { Mannital salt agar: } \\
\text { Yellow zone around the colonies. }\end{array}$ \\
\hline Escherichia coli & Lactose fermenting pink coloured colonies & $\begin{array}{l}\text { Endo Agar: A faint pink colour } \\
\text { Colonies }\end{array}$ \\
\hline Shigella spp. & Non-lactose fermenting colourless colonies & $\begin{array}{l}\text { Hektoen enteric Agar: Colourless } \\
\text { colonies }\end{array}$ \\
\hline Salmonella spp. & Non-lactose fermenting colourless colonies & $\begin{array}{l}\text { Hektoen enteric Agar: Black color } \\
\text { colony }\end{array}$ \\
\hline
\end{tabular}

Table 3: Preliminary identification of bacteria isolates based on biochemical tests

\begin{tabular}{|l|l|l|l|l|l|}
\hline $\begin{array}{l}\text { Bacterial } \\
\text { species }\end{array}$ & Gram staining & Motility & Catalase & Indole test & Oxidase test \\
\hline $\begin{array}{l}\text { Staphylococcus } \\
\text { aureus }\end{array}$ & $\begin{array}{l}\text { Gram positive Cocci arranged in } \\
\text { grape like clusters }\end{array}$ & Non-motile & Positive & Negative & Negative \\
\hline Escherichia coli & Gram negative & Motile & Positive & Positive & Negative \\
\hline Shigella spp. & Gram negative & Non-motile & Positive & Negative & Negative \\
\hline Salmonella spp. & Gram negative & Motile & Positive & Negative & Negative \\
\hline
\end{tabular}


Prevalence of rate of bacterial pathogens isolated from various denominations of Ethiopian paper currency samples collected from different sources

The result in the Table 4 revealed the prevalence rate of Staphylococcus aureus isolated from various denominations of Ethiopian paper currency samples collected from different sources such as market, taxi drivers, fruit sellers and hotels. Totally 50 number of isolates from 240 sample were positive with $S$. aureus. The perveance rate of $S$. aureus was higher
$(11.66 \%)$ in the currency samples collected from the market source than currency samples collected from taxi drivers $(5 \%)$, fruit sellers $(2.5 \%)$ and hotels $(1.66 \%)$. In case of prevalence rate based on the currency notes denominations, the least value paper currency denomination especially $5 \mathrm{birr}$ showed highest prevalence rate of $10.83 \%$ followed by 10 birr paper currency which resulted the prevalence rate of $5 \%$. The lowest level of prevalence rate $2.08 \%$ was found to be with highest value paper currency of $100 \mathrm{birr}$.

Table 4: The prevalence rate of Staphylococcus aureus isolated from different denominations of Ethiopian paper currency notes collected from different sources

\begin{tabular}{|c|c|c|c|c|c|c|c|c|c|c|c|c|}
\hline \multirow[t]{3}{*}{ S.No. } & \multirow{3}{*}{$\begin{array}{l}\text { Paper } \\
\text { Currency } \\
\text { Denominations }\end{array}$} & \multicolumn{8}{|c|}{ Sample Source } & \multirow{3}{*}{ 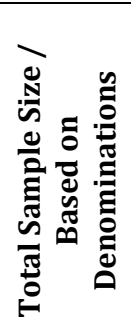 } & \multirow{3}{*}{ 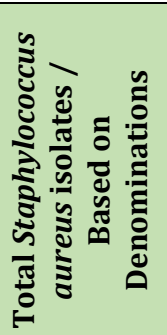 } & \multirow{3}{*}{ 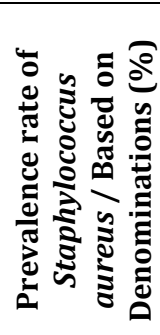 } \\
\hline & & \multicolumn{2}{|c|}{ Market } & \multicolumn{2}{|c|}{$\begin{array}{l}\text { Taxi } \\
\text { Drivers }\end{array}$} & \multicolumn{2}{|c|}{$\begin{array}{l}\text { Fruit } \\
\text { Sellers }\end{array}$} & \multicolumn{2}{|c|}{ Hotels } & & & \\
\hline & & 之: &  & 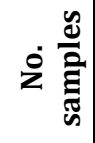 & $\begin{array}{l}\ddot{0} \\
\dot{0} \\
\dot{z}\end{array}$ & 之 $\frac{\mathscr{E}}{\tilde{Z}}$ & $\begin{array}{l}\square \\
0 \\
\dot{0} \\
z\end{array}$ & 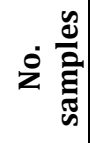 & $\begin{array}{l}\longleftarrow \\
\dot{0} \\
\dot{0} \\
\dot{0}\end{array}$ & & & \\
\hline 1 & 5 birr & 15 & 13 & 15 & 6 & 15 & 4 & 15 & 3 & 60 & 26 & 10.83 \\
\hline 2 & 10 birr & 15 & 7 & 15 & 3 & 15 & 1 & 15 & 1 & 60 & 12 & 5 \\
\hline 3 & 50 birr & 15 & 5 & 15 & 1 & 15 & 1 & 15 & 0 & 60 & 7 & 2.9 \\
\hline 4 & 100 birr & 15 & 3 & 15 & 2 & 15 & 0 & 15 & 0 & 60 & 5 & 2.08 \\
\hline \multicolumn{2}{|c|}{$\begin{array}{l}\text { Total sample size / } \\
\text { Based on sample source }\end{array}$} & 60 & & 60 & & 60 & & 60 & & 240 & & \\
\hline \multicolumn{3}{|c|}{$\begin{array}{l}\text { Total no. of Staphylococcus } \\
\text { aureus isolates / Based on } \\
\text { sample source }\end{array}$} & 28 & & 12 & & 6 & & 4 & & 50 & \\
\hline \multicolumn{3}{|c|}{$\begin{array}{l}\text { Prevalence rate of } \\
\text { Staphylococcus aureus based on } \\
\text { the source (\%) }\end{array}$} & 11.66 & & 5 & & 2.5 & & 1.66 & \multicolumn{3}{|c|}{$\begin{array}{c}\text { Over all prevalence rate of } \\
\text { Staphylococcus aureus }=20.8 \%\end{array}$} \\
\hline
\end{tabular}

The result in the Table 5 indicated that the prevalence rate of Escherichia coli isolated from various denominations of Ethiopian paper currency samples collected from different sources such as market, taxi drivers, fruit sellers and hotels. Totally 35 number of isolates from 240 sample were positive with $E$. coil. In case of the prevalence rate based on the Ethiopian paper currency denominations such as 5birr, $10 \mathrm{birr}$, 50birr and $100 \mathrm{birr}$, the highest prevalence rate of $5 \%$ was found to be with lowest value paper currency denomination of 5birr followed by 10 birr denomination (4.16\%). In case of the E. coli prevalence rate based on the currency sample source, the highest prevalence rate $(7.5 \%)$ was found to be with currency samples collected from market place followed by currency samples collected from taxi drivers (3.75\%) and fruit sellers $(2.08 \%)$. The lowest rate of prevalence $(1.25 \%)$ was found to be in the currency samples collected from the hotels.

The result in the Table 6 showed the prevalence rate of Shigella species isolated from various denominations of Ethiopian paper currency samples collected from different sources such as market, taxi drivers, fruit sellers and hotels. Totally 26 number of isolates from 240 sample were positive with Shigella sp. The perveance rate of Shigella sp. was higher $(5.41 \%)$ in the currency samples collected from the market source than currency samples collected from taxi drivers $(2.91 \%)$, fruit sellers $(21.66 \%)$ and hotels $(0.83 \%)$. In case of prevalence rate based on the currency note denominations, the least value paper currency denomination especially 5birr showed highest prevalence rate of $4.58 \%$ followed by 10birr paper currency which resulted the prevalence rate of $2.91 \%$. The lowest level of prevalence rate $1.25 \%$ was found to be with highest value paper currency of 100birr.

The result in the Table -7 revealed the prevalence rate of Salmonella species isolated from various denominations of Ethiopian paper currency samples collected from different sources such as market, taxi drivers, fruit sellers and hotels. Totally 9 number of isolates from 240 sample were positive with Salmonella species. In case of the prevalence rate based on the Ethiopian paper currency denominations such as 5 birr, 10 birr, $50 \mathrm{birr}$ and $100 \mathrm{birr}$, the highest prevalence rate of $1.66 \%$ was found to be with lowest value paper currency denomination of 5 birr followed by 10 birr denomination $(1.25 \%)$. In case of the Salmonella sp. prevalence rate based on the currency sample source, the highest prevalence rate of $1.66 \%$ was found to be with currency samples collected from market place followed by currency samples collected from taxi drivers (1.25\%) and fruit sellers $(0.83 \%)$. The Salmonella sp. was absent in all the denominations of currency samples collected from the hotels. Overall prevalence of bacterial isolates was assessed and recorded in Table 4-7. Out of 240 samples screened, 120 samples were culture positive $120(50 \%)$. Among this 120-culture positive, four different genus such as such as Staphylococcus aureus $50(20.8 \%)$, E. coli $35(14.58 \%)$, Shigella spp. 26(10.83\%), and Salmonella spp. 9(3.75\%) were identified. 
Table 5: The prevalence rate of Escherichia coli isolated from different denominations of Ethiopian paper currency notes collected from different sources

\begin{tabular}{|c|c|c|c|c|c|c|c|c|c|c|c|c|}
\hline \multirow[t]{3}{*}{ S.No. } & \multirow{3}{*}{$\begin{array}{l}\text { Paper } \\
\text { Currency } \\
\text { Denominations }\end{array}$} & \multicolumn{8}{|c|}{ Sample Source } & \multirow{3}{*}{ 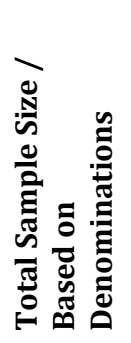 } & \multirow{3}{*}{ 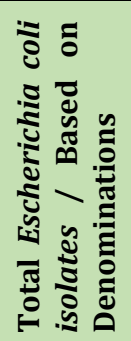 } & \multirow{3}{*}{ 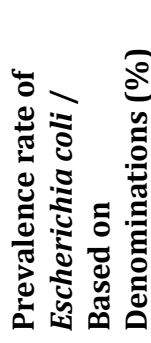 } \\
\hline & & \multicolumn{2}{|c|}{ Market } & \multicolumn{2}{|c|}{$\begin{array}{l}\text { Taxi } \\
\text { Drivers }\end{array}$} & \multicolumn{2}{|c|}{$\begin{array}{l}\text { Fruit } \\
\text { Sellers }\end{array}$} & \multicolumn{2}{|c|}{ Hotels } & & & \\
\hline & & $\dot{\vdots} \frac{\tilde{d}}{\tilde{z}}$ & 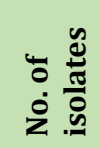 & ¿ & $\begin{array}{l}\stackrel{\mathscr{d}}{\frac{\pi}{\pi}} \\
\dot{0} \\
\dot{0}\end{array}$ & 之 & 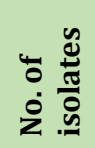 & 之 & 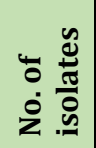 & & & \\
\hline & 5 birr & 15 & 7 & 15 & 3 & 15 & 1 & 15 & 1 & 60 & 12 & 5 \\
\hline & 10 birr & 15 & 4 & 15 & 3 & 15 & 2 & 15 & 1 & 60 & 10 & 4.6 \\
\hline & 50 birr & 15 & 4 & 15 & 2 & 15 & 1 & 15 & 1 & 60 & 8 & 3.33 \\
\hline & 100 birr & 15 & 3 & 15 & 1 & 15 & 1 & 15 & 0 & 60 & 5 & 2.08 \\
\hline $\begin{array}{l}\text { Total } \\
\text { Based }\end{array}$ & $\begin{array}{l}\text { sample size / } \\
\text { on sample source }\end{array}$ & 60 & & 60 & & 60 & & 60 & & 240 & & \\
\hline \multicolumn{3}{|c|}{$\begin{array}{l}\text { Total no. of Escherichia coli } \\
\text { isolates / Based on sample } \\
\text { source }\end{array}$} & 18 & & 9 & & 5 & & 3 & & 35 & \\
\hline \multicolumn{3}{|c|}{$\begin{array}{l}\text { Prevalence rate of Escherichia } \\
\text { coli based on the source }(\%)\end{array}$} & 7.5 & & 3.75 & & 2.08 & & 1.25 & \multicolumn{3}{|c|}{$\begin{array}{l}\text { Over all prevalence rate of } \\
\text { Escherichia coli }=14.58 \%\end{array}$} \\
\hline
\end{tabular}

Table 6: The prevalence rate of Shigella sp. isolated from different denominations of Ethiopian paper currency notes collected from different sources

\begin{tabular}{|c|c|c|c|c|c|c|c|c|c|c|c|c|}
\hline \multirow[t]{3}{*}{ S.No. } & \multirow{3}{*}{$\begin{array}{l}\text { Paper } \\
\text { Currency } \\
\text { Denominations }\end{array}$} & \multicolumn{8}{|c|}{ Sample Source } & \multirow{3}{*}{ 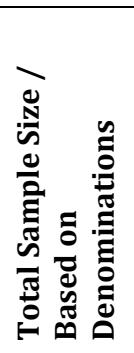 } & \multirow{3}{*}{  } & \multirow{3}{*}{ 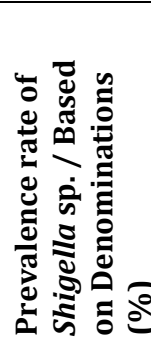 } \\
\hline & & \multicolumn{2}{|c|}{ Market } & \multicolumn{2}{|c|}{$\begin{array}{l}\text { Taxi } \\
\text { Drivers }\end{array}$} & \multicolumn{2}{|c|}{$\begin{array}{l}\text { Fruit } \\
\text { Sellers }\end{array}$} & \multicolumn{2}{|c|}{ Hotels } & & & \\
\hline & & z &  & ¿ &  & ¿ &  & z & 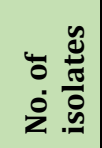 & & & \\
\hline 1 & 5 birr & 15 & 5 & 15 & 3 & 15 & 2 & 15 & 1 & 60 & 11 & 4.58 \\
\hline 2 & 10 birr & 15 & 3 & 15 & 2 & 15 & 1 & 15 & 1 & 60 & 7 & 2.91 \\
\hline 3 & 50 birr & 15 & 3 & 15 & 1 & 15 & 1 & 15 & 0 & 60 & 5 & 2.08 \\
\hline 4 & 100 birr & 15 & 2 & 15 & 1 & 15 & 0 & 15 & 0 & 60 & 3 & 1.25 \\
\hline \multicolumn{2}{|c|}{$\begin{array}{l}\text { Total sample size / } \\
\text { Based on sample source }\end{array}$} & 60 & & 60 & & 60 & & 60 & & 240 & & \\
\hline \multicolumn{3}{|c|}{$\begin{array}{l}\text { Total no. of Shigella sp. isolates / } \\
\text { Based on sample source }\end{array}$} & 13 & & 7 & & 4 & & 2 & & 26 & \\
\hline \multicolumn{3}{|c|}{$\begin{array}{l}\text { Prevalence rate of Shigella sp. } \\
\text { based on the source }(\%)\end{array}$} & 5.41 & & 2.91 & & 1.66 & & 0.83 & \multicolumn{3}{|c|}{$\begin{array}{l}\text { Over all prevalence rate of Shigella } \\
\text { sp. }=10.81 \%\end{array}$} \\
\hline
\end{tabular}


Table 7: The prevalence rate of Salmonella sp. isolated from different denominations of Ethiopian paper currency notes collected from different sources

\begin{tabular}{|c|c|c|c|c|c|c|c|c|c|c|c|c|}
\hline \multirow[t]{3}{*}{ S.No. } & \multirow{3}{*}{\begin{tabular}{l|} 
Paper \\
Currency \\
Denominations
\end{tabular}} & \multicolumn{8}{|c|}{ Sample Source } & \multirow{3}{*}{ 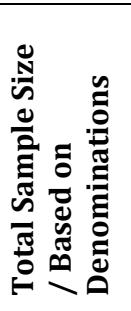 } & \multirow{3}{*}{ 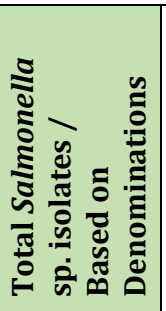 } & \multirow{3}{*}{ 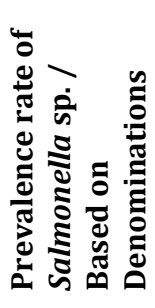 } \\
\hline & & \multicolumn{2}{|c|}{ Market } & \multicolumn{2}{|c|}{\begin{tabular}{l|} 
Taxi \\
Drivers
\end{tabular}} & \multicolumn{2}{|c|}{$\begin{array}{l}\text { Fruit } \\
\text { Sellers }\end{array}$} & \multicolumn{2}{|c|}{ Hotels } & & & \\
\hline & & ¿ & 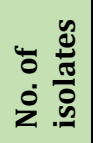 & ¿ & 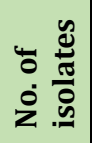 & 之 &  & ¿ & 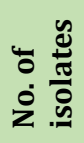 & & & \\
\hline 1 & 5 birr & 15 & 2 & 15 & 1 & 15 & 1 & 15 & 0 & 60 & 4 & 1.66 \\
\hline 2 & 10 birr & 15 & 1 & 15 & 1 & 15 & 1 & 15 & 0 & 60 & 3 & 1.25 \\
\hline 3 & 50 birr & 15 & 1 & 15 & 1 & 15 & 0 & 15 & 0 & 60 & 2 & 0.83 \\
\hline 4 & 100 birr & 15 & 0 & 15 & 0 & 15 & 0 & 15 & 0 & 60 & 0 & 0 \\
\hline \multicolumn{2}{|c|}{$\begin{array}{l}\text { Total sample size / } \\
\text { Based on sample source }\end{array}$} & 60 & & 60 & & 60 & & 60 & & 240 & & \\
\hline \multicolumn{3}{|c|}{$\begin{array}{l}\text { Total no. of Salmonella sp. } \\
\text { isolates / Based on sample } \\
\text { source }\end{array}$} & 4 & & 3 & & 2 & & 0 & & 9 & \\
\hline \multicolumn{3}{|c|}{$\begin{array}{l}\text { Prevalence rate of Salmonella } \\
\text { sp. based on the source (\%) }\end{array}$} & 1.66 & & 1.25 & & 0.83 & & 0 & \multicolumn{3}{|c|}{$\begin{array}{l}\text { Over all prevalence rate of } \\
\text { Salmonella sp. }=3.74 \%\end{array}$} \\
\hline
\end{tabular}

\section{Sensitivity/resistant pattern of bacterial pathogens isolated from various denominations of Ethiopian paper currency samples collected from different sources}

Sensitivity/Resistant percentage of various classes of antibiotics against Staphylococcus aureus and Escherichia coli were assessed and recorded in Table 8. Twelve different antibiotics were implemented against isolates of Staphylococcus aureus, among that Tobramycin 10(20\%) antibiotic was showed sensitivity followed by Aztreonam (8)16\% and Amoxicillin 8(16\%). It was interestingly noted that $80 \%$ of the $S$. aureus isolates showed resistant against all the twelve different antibiotics. The highest level of resistant was observed against Penicillin 49(98\%) and Erythromycin $49(98 \%)$ followed by Metronidazole 48(96\%) and Clarithromycin $48(96 \%)$. Only one isolate of $S$. aureus showed intermediate against Tetracycline 1(2\%) and Kanamycin 1(2\%). Further these isolates were implemented for retest and the same result was obtained. Among 35 number of $E$. coli isolates, $14 \%$ of the isolates showed sensitive against Metronidazole and $4 \%$ of the isolates showed sensitive against Amoxicillin and Cefoxitin. Based on the sensitivity, a few d antibiotics such as Metronidazole, Amoxicillin and Cefoxitin were considered to be best drug of choice against Escherichia coli. Whereas, Erythromycin 35(100\%) and Aztreonam 34(97\%) showed resistant against
Escherichia coli. Only one intermediate result was recorded against Kanamycin and that isolates were closely nearby resistant buffer zone.

Table 9 showed sensitivity/resistant pattern of various classes of antibiotics against Shigella sp. and Salmonella sp. Twelve different antibiotics were admitted against all 26 isolates of Shigella, all the 26 isolates showed resistant against Penicillin antibiotics and $96 \%$ isolates showed resistant against Amoxicillin. Among 26 isolates of Shigella sp. 3 isolates showed sensitive against Tobramycin antibiotic. A few intermediate results were recorded against Kanamycin 1(3.84\%) and Tetracycline 1(3.84\%). In case of Salmonella, (3)33\% sensitivity was documented with Tobramycin antibiotics. Highest resistant was observed against Cotrimoxazole8 (88.9\%), Cefoxitin 8 (88.9\%), and Erythromycin 8 (88.9\%), followed by Amoxicillin 7(77.8\%), Penicillin 7(77.8\%), Metronidazole (77.8\%), Co-trimoxazole (77.8\%), Aztreonam (77.8\%), Tetracycline (77.8\%), and clarithromycin (77.8\%). The result revealed that most of the isolates of Salmonella resistant against all twelve antibiotics. Based on present result, Tobramycin antibiotic is the best drug of choice for Salmonella isolates. A few classes of antibiotics given buffer zone result and all the result were closely nearby resistant zone.

Table 8: Antimicrobial susceptibility patterns of $S$. aureus and E. coli against different antibiotics

\begin{tabular}{|c|c|c|c|c|c|c|}
\hline \multirow{2}{*}{$\begin{array}{l}\text { Antibacterial agents } \\
\text { and its strength } \\
\text { (micro gram) }\end{array}$} & \multicolumn{3}{|c|}{ Staphylococcus aureus $-(\mathrm{n}=50)$} & \multicolumn{3}{|c|}{ Escherichia coli $-(n=35)$} \\
\hline & S(\%) & I (\%) & R (\%) & S (\%) & I (\%) & R (\%) \\
\hline Penicillin-10 $\mu \mathrm{g}$ & $1(2 \%)$ & - & $49(98 \%)$ & $2(5.7 \%)$ & - & $33(94 \%)$ \\
\hline Amoxicillin $(10 \mu \mathrm{g})$ & $8(16 \%)$ & - & $42(84 \%)$ & $4(11.42 \%)$ & - & $31(88 \%)$ \\
\hline Kanamycin $(10 \mu \mathrm{g})$ & $3(6 \%)$ & $1(2 \%)$ & $46(92 \%)$ & $3(8.5 \%)$ & $1(2.8 \%)$ & $31(88 \%)$ \\
\hline Metronidazole $(5 \mu \mathrm{g})$ & $2(4 \%)$ & - & $48(96 \%)$ & $5(14.28 \%)$ & - & $30(86 \%)$ \\
\hline Cotrimoxazole $(25 \mu \mathrm{g})$ & $4(8 \%)$ & - & $46(92 \%)$ & $3(8.5 \%)$ & - & $32(91 \%)$ \\
\hline Cefoxitin $(30 \mu \mathrm{g})$ & $3(6 \%)$ & - & $47(94 \%)$ & $4(11.42 \%)$ & - & $31(88 \%)$ \\
\hline Co-trimoxazole $(25 \mu \mathrm{g})$ & $5(10 \%)$ & - & $45(90 \%)$ & $3(8.5 \%)$ & - & $32(91 \%)$ \\
\hline Aztreonam $(10 \mu \mathrm{g})$ & $8(16 \%)$ & - & $42(84 \%)$ & $1(2.8 \%)$ & - & $34(97 \%)$ \\
\hline Tetracycline $(30 \mu \mathrm{g})$ & $7(14 \%)$ & $1(2 \%)$ & $42(84 \%)$ & $2(5.7 \%)$ & - & $33(94 \%)$ \\
\hline Erythromycin $(30 \mu \mathrm{g})$ & $1(2 \%)$ & - & $49(98 \%)$ & - & - & $35(100 \%)$ \\
\hline Tobramycin $(10 \mu \mathrm{g})$ & $10(20 \%)$ & - & $40(80 \%)$ & $3(8.5 \%)$ & - & $32(91 \%)$ \\
\hline Clarithromycin $(15 \mu \mathrm{g})$ & $2(4 \%)$ & - & $48(96 \%)$ & $2(5.7 \%)$ & - & $33(94 \%)$ \\
\hline
\end{tabular}

(S)-Sensitivity, (I) - Intermediate, (R) - Resistant 
Table 9: Antimicrobial susceptibility patterns of Shigella sp. and Salmonella sp. against different antibiotics

\begin{tabular}{|c|c|c|c|c|c|c|}
\hline \multirow{2}{*}{$\begin{array}{l}\text { Antibacterial agents } \\
\text { and its strength } \\
\text { (micro gram) }\end{array}$} & \multicolumn{3}{|c|}{ Shigella sp. - $(n=26)$} & \multicolumn{3}{|c|}{ Salmonella sp. - $(n=9)$} \\
\hline & S (\%) & I (\%) & R (\%) & S (\%) & I (\%) & R (\%) \\
\hline Penicillin $(10 \mu \mathrm{g})$ & - & - & $26(100 \%)$ & $2(22.2 \%)$ & - & $7(77.8 \%)$ \\
\hline Amoxicillin $(10 \mu \mathrm{g})$ & $1(3.84 \%)$ & - & $25(96.1 \%)$ & $1(11.1 \%)$ & $1(11.1 \%)$ & $7(77.8 \%)$ \\
\hline Kanamycin $(10 \mu \mathrm{g})$ & $1(3.84 \%)$ & $1(3.84 \%)$ & $24(92.3 \%)$ & $2(22.2 \%)$ & $1(11.1 \%)$ & $6(66.7 \%)$ \\
\hline Metronidazole $(5 \mu \mathrm{g})$ & $1(3.84 \%)$ & - & $25(96.1 \%)$ & $2(22.2 \%)$ & - & $7(77.8 \%)$ \\
\hline Cotrimoxazole $(25 \mu \mathrm{g})$ & $2(7.7 \%)$ & - & $24(92.3 \%)$ & $1(11.1 \%)$ & - & $8(88.9 \%)$ \\
\hline Cefoxitin $(30 \mu \mathrm{g})$ & $1(3.84 \%)$ & - & $25(96.1 \%)$ & $1(11.1 \%)$ & - & $8(88.9 \%)$ \\
\hline Co-trimoxazole (25) & $2(7.7 \%)$ & - & $24(92.3 \%)$ & $2(22.2 \%)$ & - & $7(77.8 \%)$ \\
\hline Aztreonam $(10 \mu \mathrm{g})$ & $1(3.84 \%)$ & - & $25(96.1 \%)$ & $2(22.2 \%)$ & - & $7(77.8 \%)$ \\
\hline Tetracycline $(30 \mu \mathrm{g})$ & $1(3.84 \%)$ & $1(3.84 \%)$ & $24(92.3 \%)$ & $1(11.1 \%)$ & $1(11.1 \%)$ & $7(77.8 \%)$ \\
\hline Erythromycin $(30 \mu \mathrm{g})$ & $2(7.7 \%)$ & - & $24(92.3 \%)$ & $1(11.1 \%)$ & - & $8(88.9 \%)$ \\
\hline Tobramycin $(10 \mu \mathrm{g})$ & $3(11.5 \%)$ & - & $23(88.5 \%)$ & $3(33.3 \%)$ & - & $6(66.7 \%)$ \\
\hline Clarithromycin $(15 \mu \mathrm{g})$ & $2(7.7 \%)$ & - & $24(92.3 \%)$ & $2(22.2 \%)$ & - & $7(77.8 \%)$ \\
\hline
\end{tabular}

(S)-Sensitivity, (I) - Intermediate, (R) - Resistant

\section{DISCUSSION}

The different denominations of Ethiopian paper currency notes used in this study showed different levels of contamination with some denominations having high counts and others lower counts. The total aerobic mesophilic bacterial count was higher in the less value paper currency of five-birr (5birr) denomination collected from all the sources such as market, taxi drivers, fruit sellers, and hotels. The highest value of Ethiopian paper currency notes of 100birr showed very least level of bacterial contaminations when compared to other denominations. The source of contamination of the circulating notes would be due to contamination during circulation and handling as no microorganisms were isolated from new bank notes used as controls. Moreover, the observation in the present study that showed lower denominations had higher level of microbial contamination is in agreement with the findings of other workers in other countries. ${ }^{12,17}$

This present study prevalence of isolated pathogenic bacteria was staphylococcus aureus 50(20.83\%), Escherichia coli 35(14.58\%), Shigella spp., 26(10.83\%), Salmonella spp. $9(3.75 \%)$, showed that the currency denominations were contaminated with pathogenic bacteria. The 100 birr and 50birr higher denomination had lower prevalence than the other denomination such as, 5 birr and 10 birrs. These lower denominations of currency are used on routine daily basis, covering wide range of petty transactions. Moreover, the smaller denominations are more abused and are often malhandled hence, rendering the currency tattered and dirty and are more likely to be exposed to risk of being contaminated. A similar observation was also made in $\mathrm{Nepal}^{8}$ and in Nigeria, ${ }^{18}$ where currency notes of lower denomination were found to be the most contaminated due to passing through more hands than larger denominations.

This study indicated that from the selected four sites the highest level of contamination was observed from market 63 (26\%), followed by taxi driver 31(12.9\%) fruit seller $17(7.1 \%)$ and hotel 9 (3.75\%). The reason behind in market prevalence is daily exchanging by many people with poor hygiene, but in hotels there was less prevalence when compared to another selected site, this is in contradiction with the finding of Feglo and Nkansa, ${ }^{19}$ in Ghana. It is quite common that individuals who handle the notes discharge some of their body's normal flora on the currency note leading to the dissemination of microbes between the handlers. Moreover, the contamination of the notes can be detected through dust, soil, water, micro flora of the different handlers (hand, skin, etc.). Some people usually use their saliva when tally the notes. Majority of people does not bring money in wallets and pinching of paper currency is common, especially among market women, taxi drivers, fruit sellers, and hotel workers, etc. currency notes made up of cotton provide a fibrous surface, which bear great opportunity for bacterial attachment, and more long a currency notes stays in circulation, the more chances of contamination are there..$^{20}$

The other study carried out by using one hundred and twenty Indian paper currency notes of all the denominations obtained from different occupational groups in Tirunelveli City, Tamandu, India. $86.4 \%$ of currencies were contaminated with pathogenic organisms. 121 isolates from the collected Indian paper currency yielded 6 different types of bacterial species. Assessment revealed active participation of the following organisms as Escherichia coli, Salmonella, Staphylococcus aureus and Shigella spp. Rs.100, Rs.50 had more contamination; other denominations like Rs.5, Rs.10, Rs.20 had moderate contamination and less contamination with Rs.500 and Rs.1000. The study suggested that Indian paper currency notes are highly contaminated with pathogenic microorganisms and this contamination may play a significant role in transmission of infectious diseases. Hence, great care must be taken while handling money during the preparation and handling of food to avoid cross contamination. ${ }^{21}$

Pathogenic microorganisms that may survive on the currency notes may serve as potential sources of enter pathogens that cause infections and potential sporadic cases of food borne diseases. Research has shown that contaminated fomites in general and paper currency in particular, plays a key role in the spread of bacterial infections with antimicrobial resistance. Antimicrobial resistance is a global phenomenon that has resulted in high 
morbidity and mortality as a result of treatment failures and increased health care costs. From the above resulted tables, it could be observed that antibiotic testing analysis clearly indicated that bacterial isolates were resistance to the commonly used antibiotics. For example, Staphylococcus aurous is resistant to Penicillin, Amoxicillin, Kanamycin, Metronidazole, Tetracycline, Cefoxitin and Erythromycin $98 \%, 84 \%, 92 \%, 96 \%, 84 \%, 94 \%$ and $98 \%$ respectively. It is observed that almost all the understudy bacteria which are Salmonella, Shigella, S. aureus and E. coli were highly resistant to antibiotics. All bacteria isolates were resistance to Ampicillin, Cloxacillin, Penicillin and Cefuroxime which are commonly used antibiotics that have been observed in studies presenting a public health problem. Similarly, previous report on Ghanaian currency notes in 2011 had shown that bacterial isolates showed varied resistance to commonly use antibiotics with Coagulase negative staphylococci (CNS), E. faecalis and Salmonella spp. having high resistivity of $87.5 \%$ whilst $B$. cereus and $P$. aeruginosa showed $50 \%$ sensitivity. Isolates were $100 \%$ resistant to Ampicillin, Penicillin and Cefuroxime whilst Gentamicin and both Amikacin and Cotrimoxazole were $85.7 \%$ and $77.8 \%$ activity effective respectively. ${ }^{22}$

In the present study, all the isolated bacterial pathogens such as S. aureus, E. coli, Salmonella and Shigella showed resistant against most of the antibiotics. The resistance of the bacterial pathogens to the antibiotics may be due the fact that the antibiotics are inexpensive and easily available as they are easily taken without proper prescription in Ethiopia. This misuse may lead to the resistance observed. Similarly, the bacterial pathogens isolated from money were subjected to antibiotic sensitivity test and results showed that the isolates were resistance to the first-generation antibiotics. There should be public awareness of the fact that currency notes could be a source of infection and could be dangerous to health. ${ }^{23}$

\section{CONCLUSION}

Based on the above said results, the present study has concluded that the Ethiopian Paper currency notes can act as sources of harmful bacterial pathogens including Staphylococcus aureus, Escherichia coli, Shigella species and Salmonella species. The present study has also demonstrated that the Staphylococcus aureus showed high prevalence rate of $20.8 \%$ followed by Escherichia coli (14.58\%), Shigella sp. (10.81\%) and Salmonella sp. (3.74\%). This present study has also proved that the potential pathogenic bacteria isolated Ethiopian currency notes are resistant to the most widely used antibiotics and is a threat to public health. The presence of these potential antibiotic resistant bacterial pathogens in Ethiopian paper currency notes represent a significant role in the transmission of human pathogenic microorganisms. The study also provides data on the possible choice of therapeutic antimicrobial agent for infections that might arise from this organism in the study area.

\section{CONFLICT OF INTEREST: None}

\section{REFERENCES}

1. Alemu A. Microbial contamination of currency notes and coins in circulation: A potential public health hazard. Biomedicine and Biotechnology, 2014; 2(3):46-53.

2. Alabbasy AJ. A Literature Review on Microbial Contamination of Paper Currency. IJEC., 2019;18:22.

3. Agarwal Gaurav, Navin Anand, Navpreet Kaur. Assessment of microbial contamination of Indian currency notes in Mathura City, India: A cross-sectional study. Journal of Advanced Oral Research, 2015; 6(3):43-48.

4. Girma G, Ketema T, Bacha K. Microbial load and safety of paper currencies from some food vendors in Jimma Town, Southwest Ethiopia. BMC Res Notes, 2014; 7:843

5. Saripalli HR, Nandam LS, Teka Z, Kebede H. Assessment of microbial contamination of ethiopian currency notes. RJPBCS., 2014; 5:510-515

6. El-Dars FM, Hassan WM. A preliminary bacterial study of Egyptian paper money. Int J Environ Health Res., 2005; 15: 235239.

7. Basavarajappa KG, Rao PN, Suresh K. Study of bacterial, fungal, and parasitic contaminaiton of currency notes in circulation. Indian J Pathol Microbiol., 2005; 48:278-279.

8. Lamichhane Janardan, Satish Adhikary, Prson Gautam, Rajani Maharjan, Bishal Dhakal. Risk of Handling Paper Currency in Circulation Chances of Potential Bacterial Transmittance. Nepal Journal of Science and Technology, 2009; 10:161-166

9. Pal K, Das NS, Bhattacharya S. Bacteriological profile of Indian currency circulating in a tertiary care hospital in rural Bengal. IJRRMS, 2013; 3(2).

10. Musa F, Orukotan AA, Hassan RA, Mohammed-Idris ZK. Bacterial contamination of Nigerian currency notes circulating within selected markets in Kaduna Metropolis. Bayero Journal of Pure and Applied Sciences, 2019; 12(1):366-371.

11. Ventola CL. The antibiotic resistance crisis: part 1 : causes and threats. Pharmacy and therapeutics, 2015; 40(4):277.

12. Haile Alemayehu, Mogessie Ashenafi. Microbial load of Ethiopian currency notes collected from various sources. Int. J. Adv. Res. Biol. Sci., 2019; 6(4):119-126.

13. Kuria JK, Wahome RG, Jobalamin M, Kariuki SM. Profile of bacteria and fungi on money coins. East Afr Med J, 2009; 86 (4):151-5.

14. Ahmed MSU, Parveen S, Nasreen T, Feroza B. Evaluation of the microbial contamination of Bangladesh paper currency notes (Taka) in circulation. Adv Biol Res, 2010; 4 (5):266.

15. Cheesbrough M, District Laboratory Practice in Tropical Countries, Cambridge University Press, Cambridge, UK, 2006.

16. Bauer AW, Kirby MM, Sherris JC, Truck M. Antibiotic susceptibility testing by a standardized single disk method. Am J Clin. Pathol., 1966; 45:493-6.

17. Bhat N, Bhat S, Asawa K, Agarwal A. An assessment of oral health risk associated with handling of currency notes. Int J Dent Clin., 2010; 2:266-71.

18. Awel S., Eniola K.I.T. Ojo1, F. T., and Sani, A. 2010. Bacteriological quality of some Nigerian currencies in circulation. Afr. J. Microbiol. Res. 4:2231 - 2234.

19. Feglo P, Nkansah M. Bacterial load on Ghanaian currency notes. Afr. J. Microbiol. Res. 2010; 4:2375-2380.

20. Food Science Australia (FSA). 2000. Money handling in food service operations. Food Safety and Hygiene. A bulletin for the Australian Food Industry.

21. Sucilathangam G, Ajay Mal Reventh, Velvizhi G, Revathy C. Assessment of Microbial Contamination of Paper Currency Notes in Circulation. Int.J.Curr.Microbiol.App.Sci., 2016; 5(2):735-741.

22. Tagoe DNA, Adams L, Kangah VG. Antibiotic Resistant Bacterial Contamination of the Ghanaian Currency Note: A Potential Health Problem. J. Microbiol. Biotech. Res., 2011; 1 (4):37-44

23. Benjamin Emikpe, Olufunmilayo Oyero. In vitro Antibiotics Sensitivity Pattern of Some Bacteria Isolated from Nigerian Currency. Research Journal of Biological Sciences., 2007; 2(2):209-2011. 